\title{
CRIAÇÃO DE MINHOCAS Eisenia foetida EM DIFERENTES SUBSTRATOS PARA A PRODUÇÃO DE VERMICOMPOSTO
}

\author{
Elizângela Gomes de Souza ${ }^{1}$; Andréa Hentz de Mello \\ ${ }^{1}$ Discente do Curso de Agronomia, Faculdade de Ciências Agrárias de Marabá (FCAM), Universidade Federal do Pará \\ (UFPA), Marabá, Pará. Bolsista PIBEX. E-mail: elysgsouza @ hotmail.com. \\ ${ }^{2}$ Prof., ${ }^{a}$ D. Sc.., FCAM, UFPA. E-mail: andreahentz@ufpa.br.
}

RESUMO: A utilização da minhoca para produção de vermicomposto diminui o tempo de compostagem, bem como a mão de obra empregada no sistema além de estimular a coleta seletiva do lixo. A minhoca Eisenia foetida, uma das mais usadas, diariamente ingere uma quantia de alimento igual a seu próprio peso, dejetando, sob forma de húmus $60 \%$ do alimento ingerido. As principais fontes de matéria orgânicas utilizadas na vermicompostagem são o esterco animal, restos de cultura, resíduos agroindustriais, lixo domiciliar e lodo de esgoto, sendo indispensável que passem por compostagem prévia para que não ocorra a formação de gases venenosos quando da inserção das minhocas. Além de outros benefícios, a Vermicompostagem através da criação de minhocas Eisenia foetida, pode contribuir para a rentabilidade econômica do agricultor familiar, gerando um excedente em sua produção. Este trabalho tem como objetivo desenvolver e/ou difundir tecnologias de baixo custo para a reciclagem de resíduos vegetais, através da criação de minhocas Eisenia foetida; Produção e distribuição das minhocas e do vermicomposto para os agricultores familiares, difundir técnicas de preparo de compostos orgânicos, incluindo a vermicompostagem e incentivar a utilização destes insumos biológicos, bem como divulgar junto aos produtores, técnicos e estudantes de agronomia e de cursos correlatos informações atuais sobre os principais aspectos relacionados a vermicompostagem, além de servir como instrumento de promoção social e para sensibilizar, especialmente os estudantes e agricultores, sobre a importância da conservação e preservação do meio ambiente. Os minhocários serão construídos no Campus II da UFPA, na Federação das Cooperativas da Agricultura Familiar do Sul do Pará (FECAT) e na Escola Família Agrícola (EFA). Serão construídos próximos a fonte de água e do substrato e em terrenos com boa drenagem e com pequena inclinação. Os canteiros de alvenaria serão recomendados por terem maior durabilidade. Será recomendado que se utilize uma cobertura nos canteiros com folhas de babaçu para evitar a entrada de águas das chuvas e dos raios solares. As minhocas serão colocadas nos canteiros na proporção de 500 a 1000 minhocas por $\mathrm{m}^{2}$ de canteiro quando o substrato não apresentar mais variações de temperatura, diretamente na superfície do composto. Periodicamente será feito a manutenção dos canteiros, com a irrigação, alimentação e revolvimento do material, a fim de proporcionar melhor aeração do substrato. A cada 45 dias, será retirado o húmus produzido pelas minhocas, através do peneiramento. Espera-se construir 3 modelos de referência com a criação de minhocas Eisenia foetida em diferentes substratos; Produção por metro quadrado de minhocário a cada coleta de 2000 matrizes e $350 \mathrm{Kg}$ de húmus; Utilização do vermicomposto para a produção de mudas de sistemas agroflorestais; Promover integração entre programas de extensão desenvolvidos na UFPA com as turmas de $1^{\circ}$ e $2^{\circ}$ grau da Escola Família Agrícola da cidade de Marabá; Criar espaço a ser utilizado para a realização de aulas práticas de diversas disciplinas do Curso de Agronomia no Campus de Marabá; e Divulgar a importância da minhocultura e técnicas de criação da minhoca e produção de vermicomposto através de Boletins Técnicos, Palestras e Mini cursos.

PALAVRAS-CHAVE: Agricultura familiar, minhocultura, reciclagem. 